\title{
Un intento de aproximación a la imagen de Dios en el hombre según Wolfhart Pannenberg*
}

\author{
Cecilia Echeverría-Falla**
}

\begin{abstract}
Resumen: Para Pannenberg la imagen de Dios en el hombre consiste en su destino a la comunión con Dios. El hilo conductor de este artículo es la relación intrínseca entre imagen y destino, cuya consecuencia fundamental radica, a mi juicio, en la concepción de persona humana como esse ad Deum, un ser cuya única explicación consiste en ser-para-Dios. Esta terminante verdad contenida en la noción veterotestamentaria de imago Dei, es objeto de particular atención, junto a dos de sus consecuencias implícitas: la irrestricta apertura al infinito y el carácter dialogal de la persona. Se expone la clásica distinción ireniana entre imagen-modelo e imagen-copia, con la que Pannenberg intenta mostrar que el destino del hombre ha hallado cumplimiento por anticipado en la encarnación de Dios en Jesucristo, y que constituye la clave de interpretación adecuada para enfocar dinámicamente la imagen divina en el hombre.
\end{abstract}

Palabras clave: Imagen de Dios, destino, hombre, comunión con Dios, persona, Pannenberg.

Abstract: For Pannenberg the image of God in man consists of his destiny with respect to communion with God. The theme of this article is the intrinsic relationship between image and destiny, the fundamental consequence of which lies, in my opinion, with the concept of the human person as esse ad Deum, a being whose only explanation consists of being-for-God. This categorical truth found in the Old Testament notion of imago Dei is the object of particular scrutiny in this work, together with two of its implicit consequences: an unrestricted opening up to the infinite and the dialogic nature of the person. The classic Irenian distinction between image-model and imagecopy is examined as well. It was used by Pannenberg to show man's destiny has been fulfilled in advance through the incarnation of God in Jesus Christ, which is the key to adequate interpretation for dynamic consideration of the "divine image" in man.

Key words: Image of God, destiny, man communion with God, person, Pannenberg.

Résumé: Pour Pannenberg, l'image de Dieu chez l'homme consiste en son destin de communion avec Dieu. Le fil conducteur de cet article, c'est la relation intrinsèque entre image et destin, dont la conséquence fondamentale se trouve, à mon avis, dans la conception de la personne humaine en tant que esse ad Deum, un être dont l' unique explication consiste à être-pour-Dieu. Cette vérité catégorique contenue dans la notion de l'Ancien Testament d'imago Dei fait l'objet d'une attention particulière dans cette étude, conjointement à deux de ses conséquences implicites: l'ouverture illimitée sur l'infini et le caractère dialogal de la personne. Pannenberg présente aussi la distinction classique entre image-modèle et image-copie grâce à laquelle il essaie de démontrer que la destinée de l'homme trouve son accomplissement anticipé dans l'incarnation de Dieu en Jésus-Christ, et qu'elle constitue la clé de l'interprétation adéquate pour mettre en lumière, d'une manière dynamique, l'image divine chez l'homme.

Mots-clés: Image de Dieu, destin, homme, communion avec Dieu, personne, Pannenberg.

\footnotetext{
* Este artículo forma parte de un proyecto de investigación dirigido a fundamentar filosófica y teológicamente la dignidad de la persona humana, promovido por el Instituto de Antropología y Ética de la Universidad de Navarra y coordinado por el profesor Dr. Alejandro Llano (años 2008-2009).

** Doctora en Filosofía. Profesora de Filosofía en la Universidad del Istmo, Guatemala, (cefalla@gmail.com).
}

Recibido: 2009 - 11 - 05

Aprobado: 2009 - 12 - 14 


\section{Introducción}

Hoy en día existe una concordancia unánime sobre la centralidad del hombre y el valor de la vida humana ${ }^{1}$. En medio de su apabullante desorientación, el hombre contemporáneo ha intuido que en cada ser humano existe algo inédito, no sujeto a la determinación de genes, ni al color de la piel. Algo que le hace irrepetible, singular y no heredado por la sangre.

El problema es que el hombre contemporáneo no sabe qué hacer consigo mismo $\mathrm{y}$, por eso, continúan las abyecciones contra la dignidad y la vida de la persona humana. Esa realidad tan compleja, misteriosa y enigmática, es también escurridiza, difícil de aferrar. El hombre es una contradicción viviente. Consciente de sus logros, pero también de sus límites; de su coraje, pero también de sus miedos; de sus conquistas, pero también de sus fracasos; del hecho de ser único e irrepetible, pero al mismo tiempo no indispensable. El hombre vive y luego muere, pasa. Se siente dividido, disgregado, por los conflictos que laten en su estructura íntima y, a la vez, aglutinado por la unidad de un fin. Su inagotable dignidad convive estrechamente con su miseria.

La teología contemporánea no ha cerrado los ojos ante estas paradojas, es más, las ha acogido con realismo y profundidad. Entre los teólogos de este siglo que con mayor hondura han tematizado el misterio del hombre, destaca Wol-

1 Véase, por ejemplo, Concilio Vaticano II, Gaudium et spes; Juan Pablo II, Redemptor hominis; A. Gehlen, A. Gehlen, Der Mensch. Seine Natur and seine Stellung in der Welt, Frankfurt am Main, Athenäum, 1962; J. Gevaert, El problema del hombre: introducción a la antropología filosófica, traducción de A. Ortiz, Salamanca, Sígueme, 1991; W. Pannenberg, Was ist der Mensch? Die Anthropologie del Gegenwart im Lichte der Teologie, Göttingen, Vandenhoeck \& Ruprecht, 1995; Moriconi, B. (ed.), Antropologia cristiana. Biblia, teologia, cultura, Roma, Città Nuova, 2001, p. 450; Schönborn, Ch. von, El icono de Cristo. Una introducción teológica, traducción de A. Bellella, Madrid, Encuentro, 1999. fhart Pannenberg². Desde su cátedra de Teología sistemática de la Facultad evangélica de la Universidad de Münich, Pannenberg ${ }^{3}$ ha edificado un sistema filosófico-teológico de gran amplitud e interdisciplinariedad. La obra de Pannenberg dialoga con las principales corrientes antropológicas, filosóficas, sociológicas, históricas y científicas de nuestro tiempo. Su obra acomete una labor de restauración sobre las ruinas que dejó Nietzsche, entre otros, en su derribo de Dios y de la razón humana.

El cristianismo, en la obra de Pannenberg, se presenta como la intervención de Dios en la historia humana que ha alcanzado su más alta culminación en la persona de Jesucristo ${ }^{4}$. La revelación de Dios comienza con la creación del

2 Los tratados de W. Pannenberg de mayor relevancia para nuestro tema son, entre otros: El hombre como problema. Hacia una antropología teológica, traducción de R. Jimeno, Barcelona, Herder, 1976; Antropología en perspectiva teológica. Implicaciones religiosas de la teoría antropológica, traducción de M. García Baró, Salamanca, Sígueme, 1993; Teología sistemática II, traducción de G. Canal, Madrid, UPCO, 1996.

3 Wolfhart Pannenberg nace en Stettin (entonces, Alemania; hoy, Polonia) el 2-X-1928. En los primeros pasos de su trayectoria fue seguidor de Karl Barth, de quien fue alumno. Con von Rad forma el llamado "grupo de Pannenberg" o de Heildelberg. Se reconoce opositor de la teología existencial de Bultmann. En 1956 toma posesión de la cátedra de Teología sistemática de la facultad evangélica de la U. de Münich, hasta 1994. Pertenece, junto con von Rad, Bultmann, Metz, Moltmann, etc., a una generación de teólogos protestantes de gran espesor teórico. Interlocutor notable del diálogo ecuménico contemporáneo. Su apología del cristianismo está hecha a base de coherencia y argumentación racional. Pannenberg es el teólogo protestante que con más intensidad ha estudiado la doctrina y la teología católica, sintonizando con ella hasta el punto de reconocerse "filocatólico"; lo cual le ha reportado ásperas críticas por parte de los protestantes. En 1961 publica La revelación como historia, obra que supuso un desafío para las teologías dominantes en Alemania: la barthiana y la existencial. Desde entonces ha ido desarrollando su monumental proyecto teológico desde distintos campos: en el campo cristológico, epistemológico, antropológico, ecuménico, ético, etc. En 1991 ve la luz la colosal obra titulada Systematische Theologie, en 3 volúmenes. El escenario en que inicia su singladura el siglo XXI es un mundo secularizado y dominado por las sombras de la desorientación. Empero, también este tiempo se ha visto enriquecido por figuras que, como Pannenberg, buscan dar respuesta consistente a los grandes retos de este mundo. (Sobre la trayectoria vital e intelectual puede consultarse: M. Fraijó, El sentido de la historia. Introducción al pensamiento de W. Pannenberg, Madrid, Cristiandad, 1986; J. A. Martínez Camino, "Introducción" al volumen II de Pannenberg, Teología sistemática, ob. cit., pp. XI-XVIII).

4 El cristianismo, para Pannenberg, se presenta también como algo consistente, capaz de afrontar la crítica más exigente, "el Cristianismo no puede renunciar a su pretensión de verdad" (Teología sistemática, vol. II, ob. cit., p. 9 del prólogo). Pannenberg valora las conquistas del intelecto 
hombre "a imagen y semejanza de Dios" (Gen. 1 ,26). Esta verdad teologal, narrada por el relato sacerdotal del Génesis, es el fundamento antropológico alrededor del cual giran todas las otras verdades teológicas sobre el hombre. Por ser imagen de Dios, el destino del hombre es la comunión con Él, que encuentra su consumación en la conformación con la imagen de Cristo. El acontecimiento central de Jesús de Nazaret representa la luz que descubre, descifra y da a conocer el ser del hombre mismo. Sólo a través de Cristo, imagen perfecta de Dios Padre, encuentra su consumación el destino del hombre como imagen de Dios 5 . Pannenberg se propone unir la permanente realidad de la creación del hombre a imagen de Dios con la tesis según la cual la verdadera imagen de Dios es Jesucristo ${ }^{6}$.

El objetivo que persigo en este artículo consiste en examinar las reflexiones de Pannenberg, centradas en su obra cumbre, Teología sistemática, sobre el hombre como imagen de Dios, con el fin de obtener algunas luces que den respuesta a los interrogantes planteados al inicio. El núcleo de las argumentaciones va dirigido al aspecto que me parece más original e interesante de Pannenberg sobre la imagen divina en el hombre. A mi modo de ver, su planteamiento puede considerarse una teología de la vocación que reflexiona sobre el hombre constituido en imagen de Dios, pero siempre abierto, llamado, convocado a un destino eterno, a la comunión con Dios que tiene su consumación en el éschaton de Jesucristo. Desde la perspectiva divina toda existencia humana es vocacional, lo cual tiene su raíz en la llamada a ser imagen de Dios.

\section{Contenido antropológico implícito en la idea veterotestamentaria de imagen de Dios}

Pannenberg tiene el convencimiento firme de que es toda la persona humana, cuerpo y

\footnotetext{
humano y se propone "dar razón de la propia esperanza" (1 Pet 3, 15), ofreciendo razones y motivos profundos para creer. Cfr. P. O'Callaghan, "Whose Future? Pannenberg's Eschatological Verification of Theological Truth", Irish Theological Quarterly, 66/1, 2001, pp. 19-49.

5 Pannenberg, Teología sistemática, vol. II, ob. cit., p. 227.

6 Ibídem, p. 233.
}

alma, la que es imagen de Dios. El cuerpo participa de esta condición por estar animado por un alma espiritual. Hace hincapié en el tema del destino, porque es consciente de que, de no haber en el hombre una dignidad trascendente, que le viene otorgada por el destino u ordenación a la comunión con Dios y por su capacidad de entenderle y responderle, de ningún modo se podría hablar de él como imagen de Dios.

Así, cuando Pannenberg se pregunta qué es lo específico del hombre, y responde que no es su capacidad intelectual, sino su vocación o destino a la comunión con Dios, está desvinculando la función preeminente que ha tenido la razón durante siglos y está relacionando el término destino con la configuración de la naturaleza humana como imagen de Dios ${ }^{7}$.

Pannenberg subraya que la teología tradicional, desde sus orígenes en la tradición neo-testamentaria, ha tendido a afirmar que la imagen de Dios se muestra en el alma espiritual humana ${ }^{8}$, sobre todo en la facultad intelectiva. Por influjo helenístico inconsciente en el Cristianismo se concebía al alma y al cuerpo como dos sustancias distintas, aunque estrechamente vinculadas entre si $^{9}$. De todos los planteamientos cristianos, sólo Tomás de Aquino logró despojarse del lastre del dualismo platónico con su tesis del alma como forma sustancial del cuer-

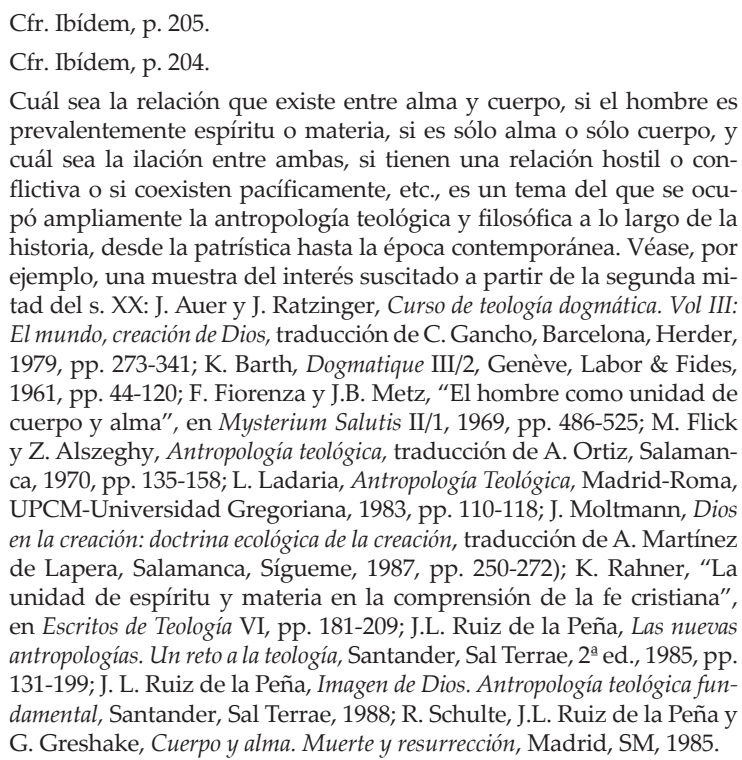
prevalentemente espíritu o materia, si es sólo alma o sólo cuerpo, y cuál sea la ilación entre ambas, si tienen una relación hostil o conflictiva o si coexisten pacíficamente, etc., es un tema del que se ocupó ampliamente la antropología teológica y filosófica a lo largo de la historia, desde la patrística hasta la época contemporánea. Véase, por ejemplo, una muestra del interés suscitado a partir de la segunda mitad del s. XX: J. Auer y J. Ratzinger, Curso de teología dogmática. Vol III: El mundo, creación de Dios, traducción de C. Gancho, Barcelona, Herder, 1979, pp. 273-341; K. Barth, Dogmatique III/2, Genève, Labor \& Fides, 1961, pp. 44-120; F. Fiorenza y J.B. Metz, "El hombre como unidad de cuerpo y alma", en Mysterium Salutis II/1, 1969, pp. 486-525; M. Flick y Z. Alszeghy, Antropología teológica, traducción de A. Ortiz, Salamanca, 1970, pp. 135-158; L. Ladaria, Antropología Teológica, Madrid-Roma, UPCM-Universidad Gregoriana, 1983, pp. 110-118; J. Moltmann, Dios en la creación: doctrina ecológica de la creación, traducción de A. Martínez de Lapera, Salamanca, Sígueme, 1987, pp. 250-272); K. Rahner, "La unidad de espíritu y materia en la comprensión de la fe cristiana", en Escritos de Teología VI, pp. 181-209; J.L. Ruiz de la Peña, Las nuevas antropologías. Un reto a la teología, Santander, Sal Terrae, 2ª ed., 1985, pp. 131-199; J. L. Ruiz de la Peña, Imagen de Dios. Antropología teológica fundamental, Santander, Sal Terrae, 1988; R. Schulte, J.L. Ruiz de la Peña y G. Greshake, Cuerpo y alma. Muerte y resurrección, Madrid, SM, 1985. 
po. Esta tesis tomista fue ratificada por el Concilio de Vienne en $1312^{10}$ que dejaba patente que el alma no es una de las partes del cuerpo, sino aquella dimensión que constituye al hombre en cuanto tal. La esencia o razón de ser del alma no es sino informar al cuerpo; de ahí que el resultado sea una unión sustancial, no accidental ${ }^{11}$. Es insuficiente entender la unión alma-cuerpo en un sentido accidental o simplemente operativo, como entidades que interactúan entre sí, como el caballo y el jinete, el piloto y la nave, etc. Es preciso afirmar que el hombre es una unidad psicofísica, corpóreo-espiritual ${ }^{12}$.

Con todo, señala Pannenberg, en Tomás hay un desplazamiento de acento, porque su visión del alma como anima intellectiva se separa un poco del relato yahvista de la creación como alma viviente, nefés hayya (Gen. 2,7), es decir, ser anhelante, ser de deseo o necesitado ${ }^{13}$. Nefés es la noción central de la antropología israelita, según algunos exégetas reconocidos ${ }^{14}$. La nefés hebrea no es una entidad puramente espiritual, al estilo de la psyché platónica ${ }^{15}$, sino que está afectada por un fuerte componente de corporeidad: cuando el ser humano siente hambre, su nefés está vacía (Is. 29, 8); el pueblo hambriento en el desierto se lamenta de tener la nefés "seca" (Num. 11, 6); la nefés disfruta con los buenos manjares (Is. 55, 2), etc ${ }^{16}$.

10 DS 902: "El alma es verdaderamente, por sí misma y esencialmente, forma del cuerpo humano". Lo que el Concilio de Vienne deja claramente asentado es que el resultado de la unión entre ambos principios es sustancial, no accidental.

11 La reacción adversa a la solución tomista antes de Vienne, había hecho correr ríos de tinta; fue llamada posteriormente, el "dilema griego". (Cfr. Ruiz de la Peña, Imagen de Dios..., ob. cit., p. 109).

12 Pese a todos los avatares de la cuestión cuerpo-alma, cuya balanza se ha inclinado, a veces hacia el dualismo, y otras veces, hacia el monismo antropológico, el lenguaje ordinario recoge en frases sintéticas la conciencia íntima del yo unitario. Nadie dice "mi cabeza tiene dolor" o "mi alma estudió mucho ayer". Estas constataciones remiten a que hay un sujeto único que las vive. (Cfr. Ibídem, p. 129).

13 Cfr. Pannenberg, Teología sistemática, vol. II, ob. cit., p. 204.

14 Por ejemplo, Pidoux y Westermann, en E. Jenni y C. Westermann, Diccionario teológico manual del Antiguo Testamento, traducción de J. A. Múgica, Madrid, Cristiandad, 1980, vol. II, p 102; D. Lys, Nèphèsh. Histoire de l'ame dans la révélation d'Israel au sein des religions proche-orientales, Paris, Presses Universitaires de France, 1959; E. Jacob, "Psyché", en TWNT IX, pp. 614-625; H. Sonnemans, Seele- Unsterblichkeit-Auferstehung, Freiburg, Freiburger Theologischen Studien 128, 1984, pp. 299-306.

15 Y ello pese a que, de las 755 veces en que aparece, los LXX traducen el término por psyché unas 680 veces; traducción -estima Westermann"insuficiente, cuando no desorientadora" (en DTMAT, ob. cit., p. 132).

16 Cfr. Ruiz de la Peña, Imagen de Dios..., ob. cit., p. 23.
La descripción que hace Aristóteles, y que sigue Santo Tomás, del alma como entelequia o forma del cuerpo se distancia del sentido bíblico de Gen. 2, 7, porque ahí "espíritu” no significa entendimiento, sino fuerza creadora de vida: “insufló en sus narices aliento de vida y resultó el hombre un ser viviente". Dios insufla en el hombre aliento de vida y así vivifica la figura por él formada de barro de la tierra. El espíritu (ruah) no es una parte constitutiva de la criatura, es una fuerza de $\operatorname{Dios}^{17}$.

Pese a que en las lenguas occidentales modernas no existe equivalencia precisa con los términos bíblicos, siguiendo las pistas insinuadas por el autor sagrado para comprender algunos conceptos claves de la antropología bíblica, Pannenberg concluye que: "El aliento de vida (nismat hayyim) del que habla Gen. 2, 7 no puede disociarse del espíritu (ruah), sino que ambos términos designan la misma realidad (cfr. esp. Gen. 6,17$)^{\prime \prime 18}$. Se trata de una fuerza creadora de vida, cuya naturaleza es la del viento, aunque en la mayoría de los casos (136 veces) ${ }^{19}$ ruah se use para denotar el espíritu de Yahvé; y en algunos casos menos, la comunicación que de este espíritu hace Yahvé al hombre ${ }^{20}$. En todo caso, "el Espíritu de Dios no se convierte, por su actuación en los seres vivos, en parte constitutiva de la criatura" 21 . No remite a partes o aspectos diversos de la estructura humana, o dicho de otro modo, no es el alma ni es el cuerpo; tampoco reproduce la dicotomía entre lo inmaterial y lo material. El espíritu (ruah) no ha de entenderse como una fuerza constitutiva del alma. Es más, es una fuerza creadora, un Espíritu divino, fuerza de Dios, que produce y conserva la vida del alma y del cuerpo. El ruah presupone, estima Pannenberg, el carácter exocéntrico de la vida creada, la apertura trascendental del ser humano que sólo puede ser colmada por la actuación vivificante del "Espíritu de Dios en

17 Pannenberg, Teología sistemática, vol. II, ob. cit., p. 200.

18 Ibídem, p. 201.

19 Cfr. H. W. Wolff, Antropología del Antiguo Testamento, traducción de S. Talavera, Salamanca, Sígueme, 1975, p. 40.

20 Cfr. Ruiz de la Peña, Imagen de Dios..., ob. cit., p. 24.

21 Pannenberg, Teología sistemática, vol. II, ob. cit., p. 201. 
cuanto que trasciende al hombre en la realización de la vida creada" 22 .

La asociación de los procesos vitales con una parte constitutiva del hombre y de su alma penetra en el pensamiento judío a través del helenismo. Debido a la insuficiencia del lenguaje bíblico y, por influjo del pensamiento griego, la teología tradicional concedió enorme importancia al nous para definir el alma humana ${ }^{23}$, llegó incluso a identificarse la razón (nous) con el espíritu (ruah). Esta identificación debería haberse evitado, porque "la actuación vivificadora del Espíritu de Dios en el hombre no se identifica con su razón. Ésta, lo mismo que todas las demás funciones vitales, necesita ser actualizada por el Espíritu creador de Dios" ${ }^{\prime 24}$. Pese a la falta de sintonía con Lutero que refleja en varios momentos de su especulación ${ }^{25}$, Pannenberg no logra desembarazarse del todo del actualismo luterano, según el cual es la providencia o el Espíritu divino el que está "animando" y "dando espíritu" a las inteligencias, y a todas las funciones vitales ${ }^{26}$.

Con todo, me parece que lo que Pannenberg intenta dejar claro es que la noción de nous, al igual que la noción de logos o psyche es insuficiente para definir al hombre, porque lo específico y distintivo del ser humano no es su capacidad intelectual, sino su destino -vocación- a la comunión con Dios.

Llegados a este punto, la referencia continua al destino a la comunión con Dios exige dilucidar la relación del destino con la configuración del ser humano como imagen de Dios. Las categorías antropológicas que emplea Pannenberg sirven

\footnotetext{
Ibídem.

Ibídem, p. 205.

Ibídem, p. 206

25 “Tampoco Lutero advirtió que la vivificante intervención del Espíritu divino en la creación se extiende a todos los seres vivos" Cfr. la interpretación que hace Lutero de Gen. 2, 7 en su lección del Génesis de 1535. (Pannenberg, Teología sistemática, vol. II, ob. cit., p. 204).

26 Así muestra otro texto que pone de manifiesto el actualismo de Pannenberg: “La razón como realidad creada necesita, lo mismo que todas las demás funciones vitales, la animación por la fuerza vital del Espíritu para su actividad, pero, en conexión con ella, necesita también la espiritualización (Begeisterung) que la eleva sobre su propia
} finitud" (Pannenberg, Teología sistemática, vol. II, ob. cit., p. 213). de sustrato para establecer un puente de unión entre ambos conceptos.

\section{Apertura al infinito}

Pannenberg mantiene que la vida humana es exocéntrica, es decir, posee una índole extática debida a su apertura al mundo (Weltoffenheit). Lo distintivo de los seres humanos es su apertura al infinito, en cuanto distinto de lo finito. "En la idea de lo finito (...), se halla implicada, al menos implícitamente, la idea de lo infinito" $^{27}$. La apertura al mundo, que caracteriza constitutivamente a la naturaleza humana, significa en último extremo una apertura que excede del mundo, de modo que su sentido propio está mejor expresado como apertura a Dios que hace posible la consideración del mundo como un todo, pues al trascender toda experiencia o representación de objetos perceptibles, el hombre permanece todavía "abierto", referido a algo distinto de él mismo.

“Debería hablarse de una apertura más allá de todo lo finito, que trasciende también el horizonte del mundo, pues precisamente sólo en la percepción de lo infinito puede formarse la idea del mundo como compendio de todo lo finito"$^{28}$. Pannenberg habla de una conciencia de lo infinito en su diferencia con lo finito que se funda en que el hombre se halla siempre extáticamente cabe lo otro que él mismo. Por su carácter excéntrico, puede el hombre percibir lo otro en tanto que otro, aprender a distinguir cada cosa en su singularidad, y formarse una idea de lo infinito frente al ámbito global de lo finito. El hombre se comporta excéntricamente respecto a $\left(\right.$ Gegenüber $\left.^{29}\right)$ una realidad que le está ya dada de antemano, y por esto en ese paso está afirmada implícitamente la realidad divina, aun sin estar captada ni temáticamente ya

Ibídem, p. 317

28 Ibídem, p. 249

29 "Sólo porque el hombre está transido de infinitud, supone un objeto de su indigencia al que se halla preordenado y que debe estar situado fuera de los límites asequibles (...). Para ese objeto que crea el campo magnético donde se anega un deseo sin fronteras ha creado el lenguaje una expresión, que es el término donde se encarna la idea, y que se llama Dios." Pannenberg, El hombre como problema. Hacia una antropología teológica, ob. cit., pp. 22-23. 
como tal, ni siquiera en alguna configuración especial ${ }^{30}$. Por eso, llega a afirmar que "los hombres se vuelven conscientes de ello en la conciencia religiosa de una fuerza divina que actúa en las realidades finitas. En todo conocimiento del mundo 'se manifiesta a la inteligencia', en las obras de Dios, su eterno poder y divinidad (Rom. 1,20)"31.

El hombre desea radicalmente un más allá. La antropología de Pannenberg concibe al hombre estructuralmente como un ser abierto que supera los límites de la finitud y espera una plenitud más allá de la muerte.

"Entre todas las demás criaturas, el hombre se distingue porque su ser se halla referido a Dios de una forma especial. En ello se apoya su vocación y facultad de dominio sobre el resto de las criaturas de Dios. Ciertamente todas las criaturas se hallan referidas a Dios como a su creador por cuanto que todas le deben la existencia y dependen continuamente de Él para su desarrollo y conservación" ${ }^{\prime 2}$. Con solo existir ya está alabando al Creador. "Pero en los hombres esta relación con Dios se convierte en algo explícito, al distinguir a Dios del propio ser y de todo lo finito. Por eso, el agradecimiento a Dios y la alabanza de Dios se convierten para el hombre en tema de la propia realización de la vida. El hombre es religioso por naturaleza. $\mathrm{Y}$ esto no queda refutado por el hecho de que

30 Esta es la cuestión problemática que algunos han tachado de a prio$r i$ religioso en el intento pannenberguiano de una fundamentación antropológica de las verdades teológicas. Expresiones como las que siguen han reforzado esta impresión sobre el teólogo alemán: "La referencia de la existencia excéntrica del hombre a lo infinito o incondicionado se da siempre mediada por un contenido finito. Pero, en el sentido inverso, cabe decir también que toda referencia humana a objetos finitos implica ya una referencia a lo infinito; es decir, que está, en último extremo, religiosamente fundamentada, y que regresa al dato actual desde el trascendimiento de todos los datos finitos (...) Este algo infinito se da siempre en relación con la experiencia de la realidad finita; bien implícitamente, bien explícitamente en la tematización religiosa, pero siempre referido a contenidos empíricos finitos. Así pues, el camino del hombre hacia la realidad (divina) en la que poder fundar últimamente su existencia excéntrica y en la que poder, por lo tanto, alcanzar su identidad, pasa a través de la experiencia del mundo externo (...). La apertura del hombre al mundo, la capacidad de objetividad en la relación con los objetos de nuestro mundo tiene, pues, un estrato profundo implícitamente religioso". (Pannenberg, Antropología en perspectiva teológica. Implicaciones religiosas de la teoría antropológica, traducción de M. García Baró, Salamanca, Sígueme, 1993, pp. 87-88).

31 Pannenberg, Teología sistemática, vol. II, ob. cit., p. 212

32 Ibídem, p. 316. haya también hombres que viven sin religión. También los ateos son hombres. Pero desde el punto de vista de la fe cristiana ha de afirmarse que en su vida no alcanza pleno desarrollo la condición esencial del hombre. El sentido del ser hombre es algo que, sin religión, no es plenamente perceptible para el hombre mismo" ${ }^{\prime 33}$.

Esta apertura al infinito, a mi modo de ver, se puede relacionar de alguna manera con la aspiración del hombre a Dios que desarrolla Tomás de Aquino en la Suma Teológica. “En la segunda parte de la Suma se vincula realmente esta aspiración con la condición de imagen de Dios, pero de modo que ésta es el punto de partida de la aspiración humana a Dios, y no precisamente su fin" ${ }^{\prime \prime}$. La diferencia para Pannenberg consiste en que la apertura trascendental es atemática ${ }^{35} \mathrm{y}$, en cierto modo, una anticipación del fin, del destino; en cambio, el deseo de ver a Dios "no es precisamente su fin, sino que va ligado a la idea del estado original" 36 .

Las diferencias no son sólo de matiz y, a mi juicio, no se pueden soslayar, pero ahora vamos a fijarnos en el denominador común de ambas nociones (el deseo de ver a Dios y la apertura al infinito), que caracterizan a santo Tomás y a Pannenberg, respectivamente. Ambos ven al hombre como capax Dei por el hecho de ser imagen de Dios, ontológicamente marcado por una íntima tendencia a la unión con Dios ${ }^{37}$.

"El alma", afirma santo Tomás, "es capaz de Dios (capax Dei) porque es su imagen" ${ }^{\prime 3}$. El enfoque medieval sobre el hombre como capax Dei va muy ligado a un doble aspecto: uno protológico y otro escatológico. El primero se enraí-

33 Ibídem, p. 316.

34 Ibídem, p. 237.

35 "Cada acercamiento humano a un ser u objeto finito se halla mediado por una conciencia atemática de un campo que trasciende ampliamente a cada uno de esos objetos, y que, a la luz de lo infinito, vuelve de nuevo sobre el objeto". Ibídem, p. 247.

36 Ibídem, p. 237.

37 Un punto de referencia básico sobre el tema del hombre como capax Dei es la obra de H. de Lubac, Le mystere der surnaturel, Paris, Aubier, D. L., 1965, p. 77 y ss. Acerca de este asunto véase también J. L. Ruiz de la Peña, El don de Dios. Antropología teológica especial, Santander, Sal Terrae, 1992, p. 28.

38 S. Th. III, a. 6, a. 2 c. 
za en el hombre como "imagen de Dios" y tiene como referencias bíblicas las fundadas en la tradición agustiniano-tomista: el hombre creado a "imagen de Dios" (Gen 1, 2739; Sir. 7,30"4 ; Col 3, $9 \mathrm{~s}^{41}$ ), y el "nuevo hombre" creado en Cristo (Ef. 4, $23 \mathrm{~s}^{42}$; Rom. 8, 10. 2943). Con referencia al capax Dei escatológico su perspectiva se relaciona con la "visión de Dios" y la "bienaventuranza", de acuerdo con los textos clásicos del Nuevo Testamento sobre el "ver a Dios", profusamente citados por san Agustín y santo Tomás ${ }^{44}$.

El enfoque pannenberguiano del hombre como capax Dei tiene, en cambio, un hondo acento cristológico, en el sentido de que sólo desde la apertura constitutiva del hombre puede comprenderse la apertura implícita a Dios calificada por Pannenberg como notitia Dei insita, que se sabe fundada en una automanifestación de la realidad divina, aunque sea desconocida por el hombre. A mi juicio, la visión cristocéntrica permea toda la construcción antropológica de Pannenberg, pues toda la realidad del ser humano queda reinterpretada a la luz de la encarnación de Cristo. La antropología de la imago Dei es, en este autor, objeto de una lectura cristológica y proléptica, debido a que el acontecimiento definitivo de la historia y la consumación del ser creado como distinto de Dios ya se ha realizado en Cristo anticipadamente, aunque de momento se trate de una anticipación provisoria. Sólo desde la encarnación de Cristo puede determinarse inequívocamente el sentido del destino del hombre. Y sólo por la encarnación, en definitiva, se puede definir al hombre como ser

39 “Y creó Dios a al hombre a su imagen, a imagen de Dios lo creó; varón y mujer los creó". (Gen. 1, 27).

40 "Ama con todas tus fuerzas a quien te ha creado, y no abandones a sus ministros". (Sir. 7, 30).

41 "No os engañéis unos a otros, puesto que os despojasteis del hombre viejo con sus obras". (Col. 3, 9).

42 "Para renovaros en el espíritu de vuestra mente y revestiros del hombre nuevo, que ha sido creado según Dios en la justicia y santidad de la verdad". (Ef. 4, 23-24).

43 "Pero si Cristo está en vosotros, aunque el cuerpo haya muerto por el pecado, el espíritu vive por la justicia (...). A los que de antemano conoció, también los destinó a ser semejantes a la imagen de su Hijo, para que él sea el primogénito entre muchos hermanos". (Rom. 8, 10. 29).

44 "Ahora vemos mediante un espejo, confusamente; entonces veremos cara a cara" (1 Cor 13, 9-12); "Sabemos que cuando se manifieste seremos parecidos a él, porque le veremos tal como es" (1 Io 3, 2); "Bienaventurados los limpios de corazón, porque verán a Dios" (Mt 5, 8). (Cfr. S. Pie i Ninot, Tratado de teología fundamental: dar razón de la esperanza, Salamanca, Secretariado Trinitario, $6^{\underline{a}}$ ed., 2006, p. 110). abierto a Dios. Este cristocentrismo le da a su tesis un giro novedoso y pleno de resonancias originales. Dios ha querido reflejarse en el hombre como en un espejo, pero ese rostro que reverbera la gloria de Dios sugiere desde el inicio una unión no superada por ninguna otra forma de comunión entre Dios y los hombres, que es la encarnación de Dios. Una vez que Dios se ha encarnado, ya no se puede hablar de Dios sin hablar del hombre, ni del hombre sin hablar de Dios. La antropología de la imagen de Dios apunta prolépticamente a la cristología.

Aunque ha bebido en las fuentes del luteranismo alemán y en su terminología se detectan ecos hegelianos, la teología de Pannenberg coincide en lo esencial con la reflexión razonable y razonada que hace el magisterio de la Iglesia sobre la relación que Dios establece con el hombre. El catecismo parte del destino final del hombre a la visión de Dios ${ }^{45}$, en la cual consiste la perfecta comunión con Dios ${ }^{46}$. El hombre no podría ser llamado a tal visión si su "espíritu" no fuese naturalmente capaz y dispuesto a recibir ese don ${ }^{47}$.

Se trata de una teología fundamental nuclear donde el catecismo sintetiza con la anti-

45 Catecismo de la Iglesia Católica, n. 1023, 1027 s. De ahora en adelante CEC.

46 CEC, n. 27, 45

47 CEC, n. 367. La enseñanza de la fe cristiana sobre el fin último del hombre la encontramos resumida y propuesta magistralmente en el Catecismo de la Iglesia Católica. En la primera sección de la primera parte del CEC, que tiene por objeto la "profesión de fe", encontramos el capítulo primero que se titula: "el hombre capaz de Dios". La exposición inicia diciendo: “El deseo de Dios está inscrito en el corazón del hombre, porque el hombre ha sido creado por Dios y para Dios; y Dios no cesa de atraer al hombre hacia sí, y sólo en Dios encontrará el hombre la verdad y la dicha que no cesa de buscar" (n. 27).

Esta declaración tiene como fundamento la enseñanza de la GS 19, donde se dice explícitamente que la vocación a la comunión con Dios constituye la única fuente y raíz de la singularísima dignidad y grandeza del hombre:

“La razón más alta de la dignidad humana consiste en la vocación del hombre a la comunión con Dios. El hombre es invitado al diálogo con Dios desde su nacimiento; pues no existe sino porque, creado por Dios por amor, es conservado siempre por amor; y no vive plenamente según la verdad si no reconoce libremente aquel amor y se entrega a su Creador (GS 19,1)."

Más adelante -en el cap. I, sección II, parte primera, parágrafo sextoel catecismo, haciendo propia la doctrina conciliar de la GS 12 y 24, declara: "De todas las criaturas visibles sólo el hombre es 'capaz de conocer y amar a su Creador' (GS 12,3); es la 'única criatura en la tierra a la que Dios ha amado por sí misma' (GS 24,3); sólo él está llamado a participar, por el conocimiento y el amor, en la vida de Dios. Para este fin ha sido creado y ésta es la razón fundamental de su dignidad." CEC, 356. 
gua fórmula capax Dei los ejes trascendentales sobre el hombre como potentia oboedientialis y como desiderium naturale videndi Deum ${ }^{48}$ que coincide, en sus líneas principales, con la teología de Pannenberg, que también parte del hombre como imago Dei y de su apertura trascendental y vocación a la comunión personal con Dios.

La apertura al infinito de Pannenberg concuerda, de alguna manera, con un concepto medieval, que en la contemporaneidad ha salido a la luz debido, en parte, a los estudios de Karl Rahner $^{49}$ : el de potencia obediencial, entendido en su dimensión natural, como recepción de una iniciativa totalmente gratuita, "desde lo alto" y "desde fuera". La "apertura que está más allá de todo lo finito, que trasciende el horizonte del mundo" ${ }^{\prime \prime 50}$ es una capacidad receptiva o potencia de acogida y obediencia a la comunicación con Dios. El hombre en su situación ontológica por ser creado a imagen de Dios, no sólo no experimenta una contradicción hacia el infinito, sino que tiende naturalmente a él. La acogida de la fe en Dios no es una super estructura extraña y sin interés para el hombre, no es tampoco un dispositivo especial (un chip) propio de algunos elegidos con mayor tendencia a la religiosidad. Es una capacidad fundamental, una aptitud básica y general de disponibilidad y acogida a la voluntad creadora de Dios.

La experiencia tan humana de amistad y amor entre dos personas, quizá puede arrojar luz para entender en qué consiste esta aptitud de acogida fundamental. Cuando se conoce a alguien "especial", el encuentro con esa persona hace que la monotonía de los días se vea iluminada de pronto por un destello que proyecta un colorido singular sobre lo cotidiano. Aquella existencia empieza a plenificar la vida. Desaparecen los días grises y uniformes. Pero esa nueva acogida no es algo que se pueda exigir: se ve siempre como un don inmerecido, como un

48 S. Th., I-II, q. 2, a. 8 c.

49 K. Rahner, Oyente de la palabra; fundamentos para una filosofía de la religión, traducción de E. Lator, Barcelona, Herder, 1967, p. 37.

50 Pannenberg, Teología sistemática, vol. II, ob. cit., p. 249. regalo; hay aptitud para recibirlo, pero no para demandarlo.

Lo mismo ocurre en el encuentro con Dios. Aunque Dios no se hubiera revelado, la capacidad tendría sentido como don, ya que su carácter de acogida receptiva no plantea exigencia para Dios ni para el hombre, ya que "el hombre, en su constitución existencial como ser consciente, se encuentra definido como un ser religioso, porque en la comprensión de los objetos finitos en su particularidad se halla siempre incluida la conciencia de lo infinito como condición del conocimiento y de la existencia de tales objetos" ${ }^{\prime \prime 1}$.

No plantea tampoco exigencia para el hombre en el sentido de que la apertura hacia Dios supone moverse, tender hacia la plenitud, pero no exigencia o necesidad de llegar ${ }^{52}$, ya que el hombre puede no tener la exigencia o necesidad de salir de sus propios límites en su condición de criatura limitada. Esto puede parecer paradójico, pero la gran paradoja es que Dios ha creado una criatura, un espíritu limitado en el que "el fin está presente de modo confuso" $^{\prime 2}$. En esta inquietud y en el consiguiente sentimiento de insatisfacción se insinúa un conocimiento implícito de que el horizonte último en el que brilla el verdadero sentido de todas las realidades de la vida supera todo el ámbito de lo finito. Ciertamente, esta inquietud puede ser también expresión de la debilidad humana ${ }^{54}$. La incapacidad para conformarse con la finitud de las posibilidades vitales, y el persistente sometimiento a las limitaciones de la vida puede abocar muchas veces en el desasosiego, pero "el fenómeno de la limitación humana sólo puede

51 Ibídem, p. 317.

52 Ése es el motivo que justifica la existencia de ateos o agnósticos en el mundo.

53 Pannenberg, Teología sistemática, vol. II, ob. cit., p. 248.

54 Si no fuera por la relación con Dios, el postulado del ser humano como un absoluto sería insostenible, teniendo en cuenta su evidente contingencia. El hombre es, en efecto, "el ser afectado por un crónico coeficiente de nulidad ontológica, de finitud. Si tuviese su razón de ser en sí mismo y para sí mismo, su valor no rebasaría la tasación de cualquier bien perecedero, no superaría la cotización de lo efímero." (Ruiz de la Peña, Imagen de Dios..., ob. cit., p. 178). 
a su vez comprenderse desde el trasfondo de la constitutiva apertura del hombre" ${ }^{\prime \prime 5}$.

\section{La imagen de Dios como fundamento de la personalidad del hombre concreto}

Cuando el relato sacerdotal explicita que el hombre fue creado "a imagen y semejanza" de Dios está asentando una profunda verdad teológica, una definición sobre el ser humano y una estructura antropológica que lo constituye radicalmente. Significa no sólo que el hombre ha sido hecho, sino que ha sido destinado o llamado a una vida de relación con Dios, entendido como comunión. Y que esta destinación o vocación sustenta de tal modo la raíz de su existencia, que lo constituye intrínsecamente hasta el punto de hacerlo una persona, esto es, un ser limitado capaz de auto-poseerse y auto-donarse en cuanto que es una naturaleza subsistente en sí misma. Ser persona es ser capaz de diálogo y amor, es ser capaz de experimentarse en el otro, en el tú, como misterio de un ser-en-sí que no se agota en nada de lo que el otro puede percibir desde fuera ${ }^{56}$. El ser del hombre como imagen de Dios no se agota en el hecho de tener autoconciencia, tampoco en el de ser capaz de distinguir y afirmar el propio yo frente a los demás. Tampoco, añade Pannenberg, alguien deja de ser persona cuando su autoconciencia no se ha manifestado todavía, o no se manifestará nunca. No es la autoconciencia lo que funda la personalidad sino la relación icónica con Dios abierta a un destino eterno ${ }^{57}$.

Según Pannenberg el carácter personal del individuo viene definido por la integridad anímico-corpórea, ya antes mencionada, y por la singularidad. Ésta se adquiere frente a los otros y consiste en "ser uno mismo", un sí mismo que nunca aparece definitivamente porque la persona es inaferrable: no se puede captar, objetivar; la persona, en todo caso, se debe con-

55 Pannenberg, Teología sistemática, vol. II, ob. cit., p. 249.

56 Cfr. Ibídem, p. 214

57 Cfr. Ibídem. templar. Conviene recordar que no estamos hablando de la persona como concepto, sino de la persona real, de la persona singular y concreta.

Conocer una persona no es saber cómo es; conocer a alguien es acceder a la intimidad de quién es. El yo personal es único, no cambia; pueden cambiar sus características, sus rasgos individuales, pero no su identidad personal. Esa identidad es inmutable, porque estamos frente a un absoluto, un ser de dignidad única, dotado de sacralidad por ser reflejo del mismo Dios. De ahí que afirme Pannenberg que "ser persona es más que comprensión psicológica" 58 en el sentido de que conocer a una persona no es saber cómo es, cómo reacciona, cómo vive, qué piensa y qué quiere; conocer a una persona es acceder a una intimidad radical que trasciende siempre su realidad empírica y se trasciende siempre a sí misma. "Persona no significa precisamente un papel transferible, sino el hombre mismo. Pero en el ser uno mismo se trata de la identidad en la integridad de la propia vida (...). Por eso, en la historia de nuestra vida, el ser uno mismo no ha hecho nunca su aparición definitiva. Todavía no se ha descubierto lo que verdaderamente somos $\mathrm{y}$, sin embargo, siempre estamos ya existiendo como personas" ${ }^{\prime \prime}$.

El "yo" humano surge solamente en el encuentro con el tú. A mi modo de ver, el hombre se aproxima al "otro yo" en todo hombre que sale a su encuentro, y se hace más "yo" en la medida en que el "tú" le abre posibilidades de amor, de aceptación y de verdad, en la medida en que no le mira como una cosa, sino que accede a su singularidad irrepetible. La mirada personal se dilata, se hace más penetrante, porque el amor abre infinitas posibilidades de acceso a la intimidad personal. El amor es la única manera de aprehender a un ser humano en su radicalidad más íntima y de acogerlo como un don, porque en la entrega incondicionada se registra como abreviatura de Dios, como reflejo de la donación trinitaria. Nadie puede odiar a alguien mirándole a los ojos y viendo lo que ahí se muestra. Para odiar es preciso considerar a

58 Ibídem.

59 Ibídem, p. 216. 
alguien como una cosa, un medio o un sujeto de características cambiantes, como los terroristas consideran y presentan a sus víctimas: agente de policía, político, militar. Quienes sufren el terrorismo y se oponen a él, ponen de manifiesto, en cambio, lo más personal de las víctimas: su nombre, su rostro, su familia. Destacan lo inmutable, lo más humano, lo que se acerca más a la identidad personal, a lo que no se agota en nada de lo que el otro puede percibir desde fuera. "El ser-persona trasciende todas las singularidades y cambios de las situaciones de la vida" ${ }^{\prime 60}$.

Sin embargo, se puede decir que el "yo humano" es persona, tiene identidad personal sólo y verdaderamente frente al "Tú" de Dios que lo ha creado. El "yo" humano se realiza y se perfecciona en el "Tú" divino, en el rostro del que es icono porque refleja ya aquí quién es el Padre. "La integridad de la propia vida, independientemente de su fragmentaria realización en cada instante, sólo se encuentra en la relación con su Creador" ${ }^{\prime 61}$. El giro decisivo hacia esta concepción de persona que en su singularidad tiene ante Dios un valor infinito, lo produjo el mensaje de Cristo por el que Dios se acerca a cada una de sus criaturas con amor eterno, como se muestra ejemplarmente en el amor de Dios al descarriado y perdido.

Por encima del mundo físico, la persona en el encuentro con el otro es capaz de superar la soledad y el sinsentido, porque es capaz de hablar. La persona transforma las cosas en lenguaje y presta su voz a las demás criaturas sin habla para que puedan alabar a Dios. No deja de ser significativo teológicamente el hecho de que en el contexto del relato sacerdotal Dios dirija la palabra solamente a la primera pareja humana (Gen. 1, 28: "y les dijo Dios"; Gen. 1, 29: "yo os doy"). Dios aparece en el Génesis hablando con alguien. Esto quiere decir que la vida humana desde sus orígenes es diálogo con Dios. El ser humano es ante todo un "oyente de la palabra"62. El hecho de que Dios establezca

60 Ibídem.

61 Ibídem.

62 Así lo consigna el Antiguo Testamento, donde quien no tiene esa capacidad responsorial activa es un hombre acabado (Sal. 38, 14.15: el un diálogo con el hombre viene a subrayar su vocación o destino a la comunión con Dios. Él es alguien capaz de entender a Dios y de responderle ${ }^{63}$, es alguien dialogal. La opacidad de lo meramente físico se convierte, por la persona, en transparencia. Hay algo en la persona que va más allá de las cosas. Ese algo no es el mundo, no es algo intramundano, es lo que Pannenberg llama destino a la comunión con Dios y lo que la constituye en imagen de Dios, en una imagen personal llamada a la comunión con un Dios tripersonal ${ }^{64}$.

Pannenberg llama la atención sobre lo desacertado que resulta confundir la identidad personal con la acción, el ser con el hacer. Lo que constituye la identidad de un yo estable y duradero es la unidad del ser-uno-mismo, la unidad interior. "Toda acción presupone la identidad del agente, al menos en la medida en que la identidad del agente es imprescindible para superar la distancia temporal entre propósito y ejecución de una acción"65. Comprometerse para toda la vida, en el matrimonio, o en una vida de entrega a Dios, lleva consigo el empeño de mantenerse idéntico a sí mismo de por vida, para poder cumplir la palabra dada. No se puede cumplir una promesa vital, no se puede empeñar la propia vida, si la dirección del rumbo de las acciones la ejercen las circunstancias cambiantes, las eventualidades de la vida, o el mundo contingente y oscilante de las emociones. Quien hace una promesa ha de ser fiel a sí mismo para cumplirla; el predominio existencial de la identidad del sujeto sobre la actividad temporal ha de ser permanente y estable. "Las acciones deben su unidad a una identidad

moribundo es "como un sordo", "como un mudo"). Salomón pide a Yahvé "un corazón que escuche" (1 Re 3, 9), y Dios llama al hombre singular a la existencia (Dt 6, 4-9; 30, 15-20), para dialogar con él. También los evangelios confirman este rasgo dialogal: serán dichosos los que "oyen la palabra de Dios y la guardan" (Lc 11, 28), que saben alimentarse "no sólo de pan, sino de toda palabra que sale de la boca de Dios" (Mt 4, 4). Justamente, por ser relación a Dios y a su palabra, el hombre es el más alto valor de la creación, el fin no mediatizable y al que todo está subordinado: "el sábado ha sido instituido para el hombre y no el hombre para el sábado" (Mc 2, 27; Cfr. Mt 10, 31; 12,21). (Cfr. Ruiz de la Peña, Imagen de Dios..., ob. cit., p. 63).

63 Cfr. S. J. Baez, "L'uomo nel progetto di Dio: Gen. 1-3”, en Moriconi (ed.), Antropologia cristiana..., ob. cit., 2001, p. 178.

64 Sobre el hombre como imagen del Dios trinitario puede verse A. Aranda, Identità cristiana: i fondamenti, Roma, EDUSC, 2007, pp. 133-178.

65 Pannenberg, Teología sistemática, vol. II, ob. cit., p. 218. 
del sujeto de la acción que trasciende el paso del tiempo. Por eso es necesario que se halle ya constituida la identidad del sujeto para que pueda realizarse la acción" ${ }^{\prime 66}$.

El hombre ha de poner su vida al servicio del ser, no del hacer, aunque lógicamente el hacer se siga y sea consecuencia del ser. Cuando la actividad realizada, sobre todo si es productiva o lucrativa, se convierte en el criterio exclusivo de valoración de una persona, aquello se transforma inmediatamente en instrumento de alienación, de repliegue del ser de la persona, de merma de la plenitud vital. "La identidad de la persona está sólo camino de hacerse a través de la historia de su vida. Por eso", añade Pannenberg, "debería tomarse con cautela el valor antropológico del concepto de acción" ${ }^{\prime \prime}$, para no valorar a la persona sólo por lo que hace, sino por lo que es, como ocurre con frecuencia en nuestra sociedad pragmatista. Se tiende a valorar a las personas por su currículum de logros, por sus acciones cambiantes, como si se trabajara en la selección de personal de una empresa, porque estamos inclinados a querer dominar la propia vida y la de otros mediante la acción. Este criterio de valoración resulta alienante y deshumanizador, a fortiori, en el escenario actual donde el desempleo ensombrece la vida de innumerables hombres y mujeres. El alcance de una persona viene dado -no por lo que hace- sino por lo valioso que hay en ella, y quien lo ignora, además de injusto es poco sabio porque no comprende lo que hay en la realidad del hombre: el hombre es res sacra para el hombre, como escribió Séneca.

La persona humana ha recibido de Dios no sólo el ser, sino también la continuidad en la existencia. Y hoy, como ayer, el éxito de las acciones y planes humanos, sigue dependiendo de la providencia divina, pese al enorme incremento de posibilidades de acción y a la amplia-

66 Ibídem.

67 Ibídem, p. 218. "En diversos pasajes de mi obra Antropología en perspectiva teológica", añade Pannenberg más adelante, "me he pronunciado contra la tendencia dominante de las ciencias humanas contemporáneas a sobrevalorar el concepto de acción, que halla su expresión, por así decirlo, clásica en la antropología de A. Gehlen con la tesis de que el hombre es un ser actuante" (A. Gehlen, Der Mensch. Seine Natur and seine Stellung in der Welt, Frankfurt am Main, Athenäum, 1962, pp. 33 y ss.). ción de técnicas de dominio del mundo, propio de los adelantos científicos y tecnológicos del mundo moderno ${ }^{68}$. El hombre ha de abdicar de las falsas seguridades humanas, y confiar en la paternidad benevolente de $\operatorname{Dios}^{69}$. Cuando falta esta confianza en la providencia, surge enseguida el apremio angustioso por los bienes de la tierra. No es fácil cambiar de actitud, a veces es como dar un salto en el vacío, pero si se hace, lo esencial de la vida empieza a avanzar.

\section{Relación entre imagen-modelo e imagen-copia}

La fijación del significado de las palabras 'imagen' y 'semejanza' que emplea el código sacerdotal del Génesis ha ocupado largamente a teólogos y exégetas cristianos.

Inicialmente los exégetas se dividen en dos frentes: los que consideran que los términos del relato sacerdotal 'imagen' y 'semejanza' son sinónimos, y los que hablan de una diferencia de significado pretendida deliberadamente por el autor sagrado. San Ireneo de Lyon (130200) es el primero en distinguir entre imagen y semejanza, significando respectivamente el parecido natural y sobrenatural del hombre a Dios. Ésta es la postura que prevalece en la patrística oriental y occidental hasta la Edad Media. Según la distinción categorial que establece Ireneo, la semejanza se perdió con el pecado original y la imagen permanece como tal. Aunque Pannenberg suscribe la distinción que hace Ireneo de Lyon entre imagen-copia e imagenmodelo, como luego veremos, rechaza, siendo fiel a la tradición protestante, la diferencia entre las expresiones "imagen" y "semejanza". No le parece viable ni desde el punto de vista exegético ni en cuanto al contenido. "No es sostenible exegéticamente debido al paralelismo de

68 Cfr. Pannenberg, Teología sistemática, vol. II, ob. cit., p. 218.

69 Así nos lo enseña Jesús en el hermoso himno a la providencia de Mt. 6, 25-34: "Por eso os digo: Respecto a vuestra vida, no os preocupéis acerca de qué comeréis, ni respecto a vuestro cuerpo, acerca de qué os pondréis. (...) Mirad las aves del cielo que no siembran, ni siegan, ni recogen en graneros, y vuestro Padre celestial las alimenta. (...) No andéis, pues inquietos diciendo: ¿Qué comeremos?, o ¿qué beberemos?, o ¿con qué nos vestiremos? Por todas esas cosas se afanan los gentiles. Bien sabe vuestro Padre celestial que necesitáis de todas ellas". 
las expresiones 'imagen y semejanza' en Gen. 1 , 26s; tampoco en cuanto al contenido, porque una imagen deja de ser imagen cuando ya no conserva ninguna semejanza con lo imaginado. Existen malas imágenes cuya semejanza con lo imaginado es exigua. Pero la total pérdida de cualquier semejanza significa la desaparición de la imagen misma"70.

San Agustín (354-430) es el primer representante de la tradición patrística occidental que no hace distinción entre imagen y semejanza. No es éste el caso de Santo Tomás (12251274), quien dedica considerable atención al tema de la imagen divina en el hombre. Asume y desarrolla la distinción que hace Anselmo de Laón entre vestigium (seres inanimados y no racionales), imago creationis (racionalidad humana, reflejo de la divina), imago similitudinis (racionalidad humana, reflejo de la Trinidad: memoria, inteligencia, amor) e imago recreationis (el hombre en gracia) ${ }^{71}$. Además, "distingue en su exposición de esta cuestión una doble forma de semejanza: una más general, que no sólo concierne a la relación de imagen, y otra añadida a la idea de imagen (ut subsequens ad imaginem) en cuanto que la imagen puede ser más o menos semejante con lo representado ${ }^{72}$. Pannenberg objeta que en esta alternativa no se ha tenido en cuenta la semejanza, que es necesaria en cierta medida para la esencia misma de la imagen ${ }^{73}$.

La doctrina reformadora y post-reformadora se apartó de Ireneo y tomó como idénticas las nociones de imagen y semejanza. Debido a tal identificación, al perderse la imagen de Dios con el pecado, tuvieron que admitir la pérdida también de la semejanza. Karl Barth (18861968), concretamente, minimiza la tesis de la imagen e interpreta las expresiones de Gen 1, 26 como un simple modo de señalar la diferencia entre Creador y criatura ${ }^{74}$.

\footnotetext{
70 Pannenberg, Teología sistemática, vol. II, ob. cit., p. 234.

71 Ibídem, p. 237.

72 Summa Theologiae I, 93, 9. Citado por Pannenberg, Teología sistemática, vol. II, ob. cit., p. 234

73 Cfr. Pannenberg, Teología sistemática, vol. II, ob. cit., p. 234.

74 Cfr. J. Morales, El misterio de la creación, Pamplona, Eunsa, 1994, p. 214.
}

Para una interpretación correcta de la teología de la imago Dei, Pannenberg considera que no debe establecerse diferencia de significado entre los términos 'imagen' y'semejanza', y tampoco debe vincularse la imagen de Dios con el estado original del hombre en Adán. El estatuto natural del hombre como imago Dei perdería así su fuerza novedosa. Con el fin de preservar indemne la comprensión del hombre en cuanto tal, Pannenberg hace suya la distinción de Ireneo $^{75}$ entre imagen-copia e imagen-modelo. La imagen-copia sería Adán y la imagen-modelo sería Cristo. Esta distinción ya había sido preparada por la interpretación judía de Gen. 1, 26 al referir esta afirmación a la sabiduría preexistente ${ }^{76} \mathrm{y}$ a la participación en ella del don de sabiduría por el nous ${ }^{77}$. Sin embargo, la doctrina cristiana de la imagen de Dios en el hombre ha de tener necesariamente en cuenta las afirmaciones paulinas sobre Cristo, como imagen de Dios, en la que han de transformarse todos los demás hombres, para explicar el destino del hombre en general a conformarse con la imagen de Dios. "Hay que unir la permanente realidad de la creación del hombre a imagen de Dios con la interpretación de la tesis paulina, según la cual, el hombre en cuanto tal no es la imagen de Dios, sino solamente Jesucristo, y todos los demás hombres necesitan renovar su relación con Dios de acuerdo con esta imagen" ${ }^{\prime 78}$, con el original primitivo, que sería la imagen modelo.

¿Cómo compaginar lo uno con lo otro? ¿Cómo conectar la imagen-modelo o el original primitivo con la imagen- copia? La respuesta se encuentra en el hecho de que Gen. 1, 26 (y también Gen. 5, 1 y Gen 9, 6) califica al hombre no como "imagen de Dios" sino como ser creado "a" imagen o "según" la imagen de Dios. Aquí

75 Ireneo de Lyon (130-200) es el primero de los Padres que hace una teología de la imagen y semejanza (en Adversus haereses IV-V, principalmente), abriendo así el camino a los Padres griegos y latinos. A mi modo de ver, éste es el motivo por el que Pannenberg lo toma como punto de referencia básico: "Esta teología de la imagen es la base antropológica de la teología histórico-salvífica de Ireneo" (Pannenberg, Teología sistemática, vol. II, ob. cit., p. 234).

76 Sab. 9, 9: “Contigo está la sabiduría que conoce tus obras, que estaba presente cuando hiciste el universo, y sabe lo que es agradable a tus ojos y conforme a tus mandatos".

77 Sab. 9, 2: “y con tu sabiduría formaste al hombre, para que dominara sobre las criaturas hechas por $\mathrm{ti}^{\prime \prime}$.

78 Cfr. Pannenberg, Teología sistemática, vol. II, ob. cit., p. 233. 
se halla implícita la diferencia entre imagen-modelo e imagen-copia: el hombre es imagen-copia de Dios.

¿Cómo relacionar entonces la imagen-copia con la imagen modelo? Mediante la semejanza con el modelo. La semejanza puede ser mayor o menor; cuanto mayor sea la semejanza tanto más clara será la imagen y más intensa la presencia del modelo en ella"79. La semejanza es entonces constitutiva para la esencia de la imagen, no se puede prescindir de la semejanza, pues hace que la copia del modelo se convierta en imagen en sentido más alto ${ }^{80}$. Cristo es la imagen perfecta de Dios, el original primitivo y el creyente debe conformarse con el modelo. No debe hablarse de imagen de Dios, advierte Pannenberg, pensando en un estado de perfección paradisíaca, que se perdió con el pecado de Adán, sino pensando en Cristo. La imagen de Dios en el hombre ha hallado su cumplimiento perfecto en la persona de Jesucristo. La concepción plena del hombre como imagen de Dios no se puede obtener solo a partir de una lectura veterotestamentaria: se impone la interpretación cristológica. Hay que acudir al Nuevo Testamento, donde está el original primitivo, que es Jesucristo, la imagen perfecta del Padre ${ }^{81}$. La imagen interior que es Dios debe entrar en la imagen exterior que es Cristo y, precisamente porque ambas se corresponden, podemos decir que la imagen eterna ha asumido la figura de la imagen temporal.

"La idea de Jesucristo como imagen de Dios en la que están llamados a participar los creyentes por el Espíritu (2 Cor 3,18) implica una relevancia antropológica general que no

79 Cfr. Ibídem, p. 234

80 Según algunos exégetas el binomio 'imagen' - 'semejanza' es una distinción deliberada del hagiógrafo con el fin de mitigar al segundo sustantivo. Dado que en las culturas semitas la imagen tiende a identificarse con lo imaginado, incluso a desplazarlo, decir que el hombre es tselem de Dios sería una expresión demasiado fuerte. De la tendencia a identificar la representación y lo representado surgió la prohibición de imágenes vigente en Israel (Ex. 20,4) y, todavía hoy, en el Islam. Véase, Ruiz de la Peña, El hombre imagen de Dios..., ob. cit., p. 44; L. Scheffczyk (ed.), Der Mens als Bild Gottes, Darmstadt, Wissenschaftliche Buchgesellschaft, 1969, p. XXVI; G. Auzou, En un principio, Dios creó el mundo: historia y fe, traducción de J. M. Asurmendi, Estella, Verbo Divino, 1976, p. 265.

81 Cfr. 2 Cor 4, 4; Col. 1, 15. se halla desarrollada en las afirmaciones neotestamentarias. Cuando la tematizamos, surge inevitablemente la cuestión suscitada en 1 Cor $15,45^{82}$ sobre la relación de la imagen de Dios que define a Jesucristo y es comunicada por él, con la que, según Gen. 1, 26, caracteriza a todo hombre desde la misma creación ${ }^{83}$. Pannenberg advierte que las expresiones paulinas referentes a este tema y a la tipología Adán-Cristo (Rom. 8,2984; 1 Cor 11, 785; 15, 4586, 2 Cor 4, 487; 3, 1888; Ef. 4, 2489 ; Col 3, $9^{90} \mathrm{ss}$ ), establecen una ruptura entre el primer hombre y el segundo o definitivo, entre la historia de la creación y la acción redentora de Jesús. Sin proponérselo, Pablo abre una brecha entre el primer Adán y el segundo, entre el hombre terreno y el celeste $y$, en última instancia, entre el Dios de la creación y el Dios de la redención. Ser de Adán es pertenecer al 'hombre viejo', a la condición efímera y ya caducada; por el contrario, quien es de Cristo es 'nueva creación' (2 Cor 5, 17; Gal 6, 15) ${ }^{91}$. “Mientras que en los escritos del primitivo cristianismo existen al respecto menciones inconexas (1 Cor 11, 7; Sant. 3, $9^{92}$ y, tal vez, también Rom 1, 23), junto con la idea cristológica y soteriológica de la imagen de Dios, la teología cristiana tuvo que restablecer aquí una conexión para poder mantener la unidad entre creación y redención del hombre" ${ }^{\prime \prime 3}$.

82 “En efecto, así es como dice la Escritura: 'Fue hecho el primer hombre, Adán, alma viviente'; el último Adán, espíritu que da vida”.

83 Pannenberg, Teología sistemática, vol. II, ob. cit., p. 225

84 "Pues a los que de antemano conoció, también los destinó a ser semejantes a la imagen de su Hijo, para que él sea el primogénito entre muchos hermanos" (Rom. 8, 29).

85 "El hombre no debe cubrirse la cabeza, porque es imagen y gloria de Dios; pero la mujer es gloria del hombre" (1 Cor. 11, 7).

86 “Como está escrito: 'El primer hombre, Adán, fue hecho alma viviente; el último Adán, espíritu vivificante" (1 Cor 15, 45).

87 "Para los incrédulos, cuyas inteligencias cegó el dios de este mundo, para que no vean brillar el resplandor del Evangelio de la gloria de Cristo, que es imagen de Dios" (2 Cor 4, 4).

88 "Y todos nosotros, con el rostro descubierto, reflejando como espejos la gloria del Señor, nos vamos transformando en su misma imagen, cada vez más gloriosos, según la acción del Espíritu del Señor" (2 Cor $3,18)$.

89 "Y revestiros del hombre nuevo, que ha sido creado según Dios en la justicia y santidad de la verdad" (Ef. 4, 24).

90 "No os engañéis unos a otros, puesto que os despojasteis del hombre viejo con sus obras" (Col. 3, 9).

91 Cfr. Ruiz de la Peña, El hombre imagen de Dios..., ob. cit., p. 81.

92 “Con ella -la lengua- bendecimos al Señor y Padre, y con ella maldecimos a los hombres, que han sido hechos a imagen de Dios" (Sant. 3, 9).

93 Pannenberg, Teología sistemática, vol. II, ob. cit., p. 225. 
Con esto no quiere decir Pannenberg que Pablo haya tenido una visión desviada del tema, pero pone de manifiesto que el apóstol no logra reflejar suficientemente la relevancia antropológica universal para todo hombre, creyente y no creyente, de su destino a ser imagen de Dios. No estaba en la intención del apóstol hacer un tratado de antropología cristológica ${ }^{94}$. Además, si se apuran los términos, tras establecer la dualidad entre el primer Adán y el segundo Adán de 1 Cor 15, 45, Pablo termina dándole primacía ontológica al texto del Génesis, que encuentra su culminación en Cristo, imagen perfecta del Padre, ve al primer Adán a la luz del segundo de una forma fundamentalmente nueva. Después de la encarnación es imposible separarlo: no se puede entender al hombre en cuanto tal, en su constitución intrínseca, si no es a la luz de Cristo, la imagen perfecta de Dios Padre. Sólo en la figura de Jesucristo se ha manifestado con toda su claridad la imagen de Dios en el hombre $^{95}$. Solo en Cristo se encuentra la clave de interpretación de su ser como imagen.

El nexo que restablece la unidad entre la antropología y la cristología post-paulinas es, a juicio de Pannenberg, la salida automanifestativa de la persona del Hijo en la carne, esto es, la encarnación del Verbo. Si, como apunta Ireneo, el Verbo no tuviese carne, si la dimensión corporal no estuviese presente en el Lógos, no podríamos ser imagen de la Imagen, porque para poder ser reproducida, ésta ha de ser tangible, perceptible. Si Cristo no hubiese venido "en figura humana" (Cfr. Fil 2, 7), la aspiración ética a la homoiosis, a la semejanza con la imagenmodelo sería distante y casi imposible, porque referiría la semejanza sólo al espíritu asimilándolo al Lógos Asarkos o Lógos pre-existente, como pretendían Orígenes, Atanasio y Clemente de Alejandría ${ }^{96}$. Siendo Dios incorpóreo -el Lógos Asarkos- lo único que podía ser imagen suya era lo incorpóreo humano, es decir, el alma.

\footnotetext{
94 La mayoría de los comentaristas de Pablo coinciden en señalar que es la imagen veterotestamentaria del hombre lo que suministra al apóstol la base de su visión antropológica: “el concepto paulino de hombre -salvo matices particulares- es fundamentalmente el del Antiguo Testamento" (J. A. T. Robinson, Le corps. Étude sur la theologie de Saint Paul, Lyon, Éditions du Chalet, 1966, p. 231, cfr. Ruiz de la Peña, El hombre imagen de Dios..., ob. cit., p. 70).

95 Cfr. Pannenberg, Teología sistemática, vol. II, ob. cit., p. 235.

96 Cfr. Ibídem, p. 240.
}

Sin embargo, Ireneo tiene el mérito de haber establecido sobre la base de una antropología enraizada sobre el cuerpo, "un lazo de unión de las afirmaciones veterotestamentarias sobre la creación del hombre con las del Nuevo Testamento sobre Jesucristo como imagen de Dios y sobre el destino del hombre a transformarse en esta imagen" ${ }^{\prime 97}$. Lo que define al hombre no es ni un enunciado abstracto ni el Adán del Antiguo Testamento, sino Jesucristo, "la imagen de Dios", el nuevo y verdadero Adán. "Sólo es específicamente cristiana la tesis de la encarnación en un hombre de la imagen divina preexistente, junto con la consideración de que sólo así logra el hombre el destino que lo distingue entre todas las demás criaturas" ${ }^{\prime \prime 8}$. Ireneo logró vincular cristología y antropología, porque puso a la antropología al servicio de la cristología, cosa que no se hallaba desarrollada en las afirmaciones veterotestamentarias. A diferencia de los alejandrinos, Orígenes y Atanasio, Ireneo relacionaba las afirmaciones paulinas sobre Jesucristo como imagen de Dios con el Lógos hecho hombre, y no con el Lógos preexistente (Adv. Haer. V, 16, 2), el Lógos Asarkos. Así lograba, a mi juicio, fundamentar los supuestos claves del cristianismo, la encarnación del Verbo y la resurrección de Jesús, sobre la base de una antropología englobante y unitaria.

Podemos concluir este punto afirmando que el hombre en cuanto tal no es sólo imagen de Dios, sino también de Cristo, es imagen de la Imagen. Y no sólo los creyentes, sino el hombre en general, aunque no lo sepa. La definición del hombre como imagen de Dios significa que la relación con Dios, la destinación u ordenación a la comunión con Dios está en la esencia misma de todo lo humano, no sólo del creyente, y ésta es la idea original de Pannenberg.

\section{Enfoque dinámico de la imagen divina en el hombre}

La idea veterotestamentaria de la imagen de Dios aparece planteada en términos más

97 Ibídem, p. 224.

98 Ibídem, p. 225. 
bien estáticos: el hombre es imagen y representante de Dios en el mundo. Al igual que la imagen representa al modelo (la imagen o retrato del gobernador de un país representa al gobernador frente a su pueblo), el hombre representa a Dios ante la entera creación. Los egipcios consideraban al faraón imagen y representante de la divinidad en la tierra. En la concepción bíblica la condición de imagen no se limita al rey, sino que se dice de todo hombre. Expresa el señorío de Dios sobre su creación a cuya participación y disfrute ha sido llamado el hombre. Por encima de todas las criaturas, según el relato sacerdotal del Génesis, el hombre es representante del dominio mismo de Dios sobre su creación. Pannenberg no propone identificar sin más imagen y función de dominio, sino que califica la función de dominio como consecuencia de la semejanza del hombre con Dios ${ }^{99}$.

Pannenberg propone superar el concepto de una naturaleza clausurada, invariable, dada de una vez por todas en el origen de la existencia por una imagen de Dios en el hombre en devenir, en desarrollo, como tarea. La intención de no hacer distinción entre las nociones de imagen y semejanza va encaminada a concebir la semejanza divina como empeño del hombre para completar la imagen de Cristo en nosotros. Toda la existencia cristiana ha de apuntar a esto: "a reproducir la imagen de su Hijo" (Rom. 8, 29). La imagen de Dios en el hombre no es una magnitud estática, sino una realidad dinámica cuyo desarrollo consiste en revestirse de Cristo o participar de su imagen, al decir de San Pablo: "revestíos del hombre nuevo que se va renovando (...) según la imagen de su creador" $(\mathrm{Col} 3,10)$. Este revestimiento de Cristo de acuerdo con la idea pannenberguiana de destino a la comunión con Dios está orientado al término escatológico de la configuración con Cristo por la resurrección: "Jesucristo (...) transfigurará este miserable cuerpo nuestro en un cuerpo glorioso como el suyo" (Fil 3, 21); "del mismo modo que hemos revestido la imagen del hombre terreno, revestiremos también la imagen celeste" $(1 \text { Cor } 15,49)^{100}$.

99 Cfr. Ibídem, pp. 219-220.

100 Cfr. Ruiz de la Peña, El hombre imagen de Dios..., ob. cit., p. 79.
El encuadre pannenberguiano es un enfoque dinámico de la imagen divina, porque considera que lo propio y específico de la naturaleza humana es un proyecto a realizar, un destino. "La imagen de Dios no se realizó plenamente desde los comienzos de la historia de la humanidad. Su plasmación se halla todavía en proceso"101. Adán era un mero boceto, un esbozo del hombre definitivo. No era sino "figura" (typos) del que había de venir (Rom 5, 14). Es preciso un "Adán" verdadero, un "hombre" cabal, definitivo, en quien la imagen de Dios se refleje con toda su autenticidad. Ese hombre es Cristo, “quien es imagen de Dios" (2 Cor 4, 4).

A partir del acontecimiento Jesucristo la naturaleza humana es pensada como la historia de un ser creado que no se limita a ser una simple copia del original, sino que debe irradiar el esplendor de la imagen-modelo: "el cual, es resplandor de su gloria e impronta de su sustancia" (Heb 1, 3). Y, para poder llevarlo a cabo Dios le ha dado capacidad de alteridad, de respuesta, de trascendencia, de libertad y de amor.

Desde Cristo, este ser creado con capacidad de llegar a una plenitud sobrenatural a partir de sus propias condiciones naturales es contemplado como constante camino hacia su propia plenitud, como destino, como futuro en Cristo. Por eso, para Pannenberg una de las categorías que mejor definen al ser humano como tal es el de la historia ${ }^{102}$. El ser humano es la historia que va desde el primer Adán (prolepsis) a la aparición redentora del segundo, es decir, del verdadero y definitivo ser humano por excelencia, de la auténtica imagen de Dios. El hombre es imagen de Dios, pero una imagen no acabada, sino incoada y todavía por completar (Herder diría

101 Pannenberg, Teología sistemática, vol. II, ob. cit., p. 235. Pannenberg llegó incluso a hablar de "historización de la naturaleza humana por la cristología" ("Fundamento cristológico de una antropología cristiana", en Concilium 86, 1973, p. 413).

102 Para comprender la visión pannenbergiana de la revelación como historia y la importancia que adquiere en su doctrina el concepto de anticipación (prolepsis) puede consultarse el estudio de S. Sanz Sánchez titulado El futuro creador del Dios Trinitario. Un estudio en la Teología sistemática de Wolfhart Pannenberg, Valencia, Edicep, 2007. En esta obra el autor pone de relieve la particularidad de la aportación de Pannenberg que consiste en su visión de la creación a partir del futuro del Dios trinitario, subrayando la primacía que en su pensamiento tiene la escatología, junto a la perspectiva trinitaria de la creación. 
que se trata de una imagen en devenir) y esta plenitud del proyecto desde y para el que fue creado sólo encuentra su auténtica realización en el acontecimiento de Jesucristo. Pannenberg, ayudado en este punto por el pensamiento de Herder $^{103}$, establece que la creación del hombre a imagen de Dios consiste en su mismo origen en una destinación del hombre a aquello que él debe ser y llegará a ser. De esta forma la idea de la imagen de Dios pasa a ser en nuestro autor de un inicio ya clausurado en el origen del ser humano a destino del hombre, que sólo en la consumación escatológica al final de su historia será realizado definitivamente.

\section{Relación intrínseca entre imagen y destino}

Llegados a este punto de la investigación, ya podemos aportar algunos trazos conclusivos que pongan de manifiesto la originalidad de nuestro autor en este tema, tan clásico y, a la vez, insondable de la relación icónica entre el hombre y Dios.

Las premisas fundamentales del master argument de Pannenberg son, por una parte, que la imagen de Dios en el hombre consiste en su destino a la comunión con Dios, y, por otra, que el cumplimiento de este destino se ha realizado por anticipado -prolépticamente- en la encarnación de Dios en Cristo, en la cual ha tenido lugar la máxima expresión de comunión de Dios con la humanidad. Dicho de otra manera, la unión hipostática ha marcado -antes y después- el destino del hombre en cuanto tal.

103 Herder, al hablar del hombre como imago Dei, no está presuponiendo ningún estado original de perfección del ser humano, sino que, más acorde con la perspectiva moderna evolucionista sobre la especie humana y su aparición en la historia de la vida trata de una imago Dei en devenir, en desarrollo. Ser a imagen y semejanza de Dios es la noción teleológica del ser hombre en cuanto tal, según la convicción de Herder de que "no somos todavía hombres propiamente dicho, sino que nos estamos haciendo hombres a diario" (J. G. Herder, Ideas para una filosofía de la historia de la humanidad, IX, 1, 2). Gracias a este su destino, ser imagen de Dios, es impulsado el hombre en su vida en dirección a esta meta. Sólo la fe en la Providencia hace comprensible la noción de Herder de la imagen y semejanza de Dios. Ésta es, por una parte, la meta y el destino del hombre, cuya forma definitiva (eso que Herder llama "la verdadera figura divina del hombre", Ibídem., V, 5), sólo se alcanzará en una existencia distinta. Pero, por otra parte, ya ahora está presente en esbozo en el hombre, y presta a la vida de éste una dirección y un impulso, de modo comparable a lo que sucede en la vida de los animales gracias a su aparato instintivo.
Tanto es así que a partir del acontecimiento de la encarnación sólo se puede hablar del hombre a la luz de Jesucristo, porque la única verdadera imagen de Dios es Cristo, la imagen-modelo.

Si el destino del hombre en su creación a imagen de Dios ha hallado su cumplimiento en Jesucristo, es preciso deducir que la creación del hombre a imagen de Dios se hallaba desde el inicio ya ordenada a ese cumplimiento. ¿Cómo entender de un modo más preciso esa relación? ¿Significa que la creación del hombre estaba ya ordenada en la intención de Dios a la comunión de Dios con el hombre realizada en la encarnación del Hijo de Dios? ¿O significa más bien que el mismo ser creado del hombre se caracteriza desde el principio por una referencia a Dios y a la comunión con Él que se ha realizado en Cristo $^{104}$ ? Dicho con otras palabras, la disyuntiva que plantea Pannenberg es ésta: ¿existe una relación extrínseca, es decir, en la intención de Dios pero no en la realidad creada, entre la imagen de Dios y el destino? ¿O estamos hablando de una relación intrínseca entre ambos términos del master argument?

Karl Barth presentaba la comunión del hombre con Dios, inaugurada por la alianza de Dios con Israel y llevada a cumplimiento en Jesucristo, como un designio extrínseco a la naturaleza creada del hombre ${ }^{105}$. La realidad creada del hombre no estaría en sí misma orientada a Dios y a ser con Dios, sólo estaría así en la intención del Creador. La naturaleza creada del hombre no tiene lugar, según Barth, en la temática religiosa de la vida humana, sino en un ámbito neutral, desprovisto de fundamento teologal, despojado del espacio religioso de la vida, como ocurre en las sociedades secularizadas. En el extrinsecismo de Barth la temática religiosa de la vida en el orden natural es eludida y silenciada sorprendentemente.

De acuerdo con la óptica de Pannenberg el destino a la comunión con Dios no puede ser meramente extrínseco al desarrollo real de la

104 Cfr. Pannenberg, Teología sistemática, vol. II, ob. cit., pp. 245.

105 Cfr. K. Barth., Dogmatique III/1, Genève, Labor \& Fides, 1960, p. 225. Citado por Pannenberg, Teología sistemática, vol. II, ob. cit., p. 245. 
vida humana. Tal destino no puede consistir en una intención del Creador extrínseca a la condición creada del hombre ${ }^{106}$. No puede situarse la intención del Creador de un modo tan ineficaz y extrínseco con respecto a su criatura. ¿Cómo logra Pannenberg superar la aporía estructural de la relación Creador-criatura a que conduce el extrinsecismo de Barth?

Consigue resolver la aporía acudiendo a un concepto clave, capaz de relacionar intrínsecamente la imagen de Dios y su destino y realización de la vida humana: la "disposición". La intención del Creador al crear al hombre no puede situarse en la periferia de la realidad de la criatura, como un artesano que fabrica un producto que luego será distribuido $\mathrm{y}$, por tanto, olvidado por su hacedor. Dios no modela las criaturas al margen de su función específica. Siguiendo con el ejemplo, Dios sería el artesano que modela las obras dotándoles de una configuración específica y particular acorde y coherente con la intención inicial de la tarea, aunque luego el artículo pase a otras manos y usos independientes de su fabricante.

A esta configuración específica y particular la llama Pannenberg "disposición", en el sentido de estructura o finalidad intrínseca relativa a la intención. Esta intención se incoa con el acto creador en el que Dios plasma al hombre a su imagen y semejanza. A esa incoación del proyecto divino sigue una destinación, o una vocación (llamada por Pannenberg "destino") a la comunión con Dios. Tenemos el origen y el fin, pero falta la realización por parte del hombre de la intención creadora.

En la perspectiva teológica de Pannenberg la realidad creada del hombre se caracteriza desde el inicio por ser imagen de Dios. Pero esto en Pannenberg implica un doble momento de la acción creadora: la dotación del ser "a imagen y semejanza de Dios" y la vocación (o destino) a la comunión con Dios. Dios no quiere sólo lo que la persona "ya es", sino que la llama (o la destina) a una completa realización de su des-

106 Cfr. Pannenberg, Teología sistemática, vol. II, ob. cit., pp. 247. tino personal a la luz de su ser. La misma realidad creada se caracteriza desde el principio por una referencia a Dios y a la comunión con él en virtud de su ser imagen de Dios ${ }^{107}$.

La creación del hombre a imagen de Dios se halla ordenada a su cumplimiento que se ha realizado anticipadamente en Jesucristo, pero el hombre no deja de ser tarea para sí mismo. Pannenberg lo ve como un proceso. El despliegue de la imagen divina en el hombre no ha alcanzado sentido pleno hasta que éste se descubra como un proyecto divino, una tarea, un destino al que ha de responder libremente. El hombre ha recibido un don con el ser imago Dei, que le da un valor inestimable; es preciso que exista ya en el ser una "disposición" para el desarrollo de ese don.

La relación entre el ser (imago Dei) y el destino (vocación) es intrínseca. Lo que en Dios constituye una intención finalizadora corresponde en la criatura a una estructura finalizada, a una finalidad intrínseca, inscrita en su ser. "El destino del hombre a la comunión con Dios, fundado en su creación a imagen de Dios es intrínseco a la vida humana. El destino no puede ser una intención del Creador extrínseca a la condición creada del hombre. La vida de una criatura a imagen de Dios está intrínsecamente animada por su destino divino, aun cuando el destino divino no se ha consumado aún en los orígenes de la historia humana, sino que alcanzará solamente como fin y culminación de esta historia. Pero es preciso que exista ya en el principio al menos una disposición para este fin" ${ }^{\prime 108}$.

A lo largo de estas reflexiones, he ido descubriendo la riqueza de los implícitos teológicos y filosóficos contenidos en la noción veterotestamentaria de imago Dei, epítome del bagaje conceptual antropológico a lo largo de los siglos. La relación intrínseca de la imagen de Dios con el destino del hombre, agudeza de Pannenberg, permite concebir a la persona humana no sólo como criatura de Dios, cosa que ya sería mucho, sino como un ser cuya única

107 Ibídem, p. 245.

108 lbídem, p. 245. 
explicación consiste en ser-para-Dios. El hombre es esse ad Deum desde todas las dimensiones posibles, y eso es lo que indica, mejor que ninguna otra, la fórmula de imagen de Dios; por eso, es insuperable.

\section{Bibliografía}

1. Aranda, A., Identità cristiana: i fondamenti, Roma, EDUSC, 2007.

2. Auer, J. y Ratzinger, J., Curso de teología dogmática, Vol. III: El mundo, creación de Dios, traducción de C. Gancho, Barcelona, Herder, 1979.

3. Auzou, G., En un principio, Dios creó el mundo: historia y fe, traducción de J. M. Asurmendi, Estella, Verbo Divino, 1976, p. 265.

4. Barth, K., Dogmatique III/1-2, Genève, Labor \& Fides, 1960-61.

5. Concilio Vaticano II, Constitución pastoral Gaudium et spes, 1965.

6. De Marco, P., Pannenberg: persona e società, Firenze, Centro editoriale Toscano, 1997.

7. Fiorenza, F. y Metz, J. B., “El hombre como unidad de cuerpo y alma", en Mysterium Salutis II/1, 1969, pp. 486-525.

8. Flick, M. y Alszeghy, Z., Antropología teológica, traducción de A. Ortiz, Salamanca, Sígueme, 1970.

9. Fraijó, M., El sentido de la historia. Introducción al pensamiento de W. Pannenberg, Madrid, Cristiandad, 1986.

10. García Baró, M., “W. Pannenberg y las implicaciones religiosas de la teoría antropológica", en J. de Sahagún Lucas (dir.), Nuevas antropologías del s. XX, Salamanca, Sígueme, 1994, pp. 289-304.

11. Gevaert, J., El problema del hombre: introducción a la antropología filosófica, traducción de A. Ortiz, Salamanca, Sígueme, 1991.
12. Gehlen, A., Der Mensch. Seine Natur and seine Stellung in der Welt, Frankfurt am Main, Athenäum, 1962. Versión española: El hombre: su naturaleza y su lugar en el mundo, traducción de F. C. Vevia, Salamanca, Sígueme, 1980.

13. Jacob, E., "Psyché", en TWNT IX, pp. 614-625.

14. Jenni, E. y Westermann, C., Diccionario teológico manual del Antiguo Testamento, traducción de J. A. Múgica, Madrid, Cristiandad, 1980.

15. Juan Pablo II, Carta Encíclica Redemptor hominis, 1979.

16. Ladaria, L., Antropología teológica, Madrid-Roma, UPCM-Universidad Gregoriana, 1983.

17. Lorda, J. L., Antropología. Del Concilio Vaticano II a Juan Pablo II, Madrid, Palabra, $2^{a}$ ed., 1996.

18. Lubac, H. de, Le mystère du surnaturel, Paris, Aubier, D.L., 1965.

19. Lys, D., Nèphèsh. Histoire de l'ame dans la révélation d'Israel au sein des religions procheorientales, Paris, Presses Universitaires de France,1959.

20. Martínez Camino, J. A., "Introducción” a W. Pannenberg, Teología sistemática, vol. II, traducción de G. Canal, Madrid, UPCO, 1996, pp. XI-XVIII.

21. Martínez Camino, J. A, “La teología de W. Pannenberg interpretada por M. Fraijó: crítica de una crítica", Estudios eclesiásticos, vol. 61, núm. 239, 1986, pp. 425-433.

22. Martínez Camino, J. A., “¿Por qué la filosofía?: Las razones del teólogo W. Pannenberg", Revista de Occidente, núm. 258, 2002, pp. 62-83.

23. Matito, J. R., La determinación trinitaria y cristológica de la antropología de Wolfhart Pannenberg, Salamanca, UPSA, 2002. 
24. Moltmann, J., Dios en la creación: doctrina ecológica de la creación, traducción de A. Martínez de Lapera, Salamanca, Sígueme, 1987.

25. Morales, J., El misterio de la creación, Pamplona, Eunsa, 1994.

26. Moriconi, B. (ed.), Antropologia cristiana. Bibbia, teologia, cultura, Roma, Città Nuova, 2001.

27. O'Callaghan, P., “Whose Future? Pannenberg's Eschatological Verification of Theological Truth", Irish Theological Quarterly, 66/1, 2001, pp. 19-49.

28. Pannenberg, W., "Fundamento cristológico de una antropología cristiana", en Concilium 86, 1973, p. 413).

29. Pannenberg, W., El hombre como problema. Hacia una antropología teológica, Barcelona, traducción de R. Jimeno, Herder, 1976.

30. Pannenberg, W., El destino del hombre: reflexiones teológicas sobre el ser del hombre, la elección y la historia, traducción de C. RuizGarrido, Salamanca, Sígueme, 1981.

31. Pannenberg, W., Antropología en perspectiva teológica. Implicaciones religiosas de la teoría antropológica, traducción de M. García Baró, Salamanca, Sígueme, 1993.

32. Pannenberg, W., Was ist der Mensch? Die Anthropologie del Gegenwart im Lichte der Teologie, Göttingen, Vandenhoeck \& Ruprecht, 1995.

33. Pannenberg, W., Teología sistemática, vol. II, traducción de G. Canal, Madrid, UPCO, 1996.

34. Pannenberg., W., Una historia de la filosofía desde la idea de Dios. Teología y filosofía, traducción de R. Fernández de Mururi, Salamanca, Sígueme, 2001.

35. Pannenberg., W., “Cristología y soteriología", en Iglesia viva. Revista de pensamiento cristiano, núm. 233, 2008, pp. 101-132.
36. Pie i Ninot, S., Tratado de teología fundamental: dar razón de la esperanza, Salamanca, Secretariado Trinitario, $6^{\mathrm{a}}$ ed., 2006.

37. Rahner, K., "La unidad de espíritu y materia en la comprensión de la fe cristiana", Escritos de Teología VI, pp. 181-209.

38. Rahner, K., Oyente de la palabra: fundamentos para una filosofía de la religión, traducción de E. Lator, Barcelona, Herder, 1967.

39. Robinson, J. A. T., Le corps. Étude sur la theologie de Saint Paul, Lyon, Éditions du Chalet, 1966.

40. Ruiz de la Peña, J. L., Las nuevas antropologías. Un reto a la teología, Santander, Sal Terrae, 2ae ed., 1985.

41. Ruiz de la Peña, J. L., Teología de la Creación, Santander, Sal Terrae, 1986.

42. Ruiz de la Peña, J. L., Imagen de Dios. Antropología teológica fundamental, Santander, Sal Terrae, 1988.

43. Ruiz de la Peña, J. L., El don de Dios. Antropología teológica especial, Santander, Sal Terrae, 1992.

44. Sanz Sánchez, S., El futuro creador del Dios Trinitario. Un estudio en la teología sistemática de Wolfhart Pannenberg, Valencia, Edicep, 2007.

45. Sayés, J. A., Teología de la creación, Madrid, Palabra, 2002.

46. Saranyana, J. I., "Hacia una antropología teológica. A propósito de un libro de W. Pannenberg", Scripta Theologica 10, 1978, pp. 1115-1138.

47. Scheffczyk, L. (ed.), Der Mens als Bild Gottes, Darmstadt, Wissenschaftliche Buchgesellschaft, 1969

48. Schönborn, Ch. von, El icono de Cristo. Una introducción teológica, traducción de A. Bellella, Madrid, Encuentro, 1999. 
Cecilia Echeverría-Falla

49. Schulte, R., Ruiz de la Peña, J. L.y Greshake, G., Cuerpo y alma. Muerte y resurrección, Madrid, SM, 1985.

50. Sonnemans, H., Seele-Unsterblichkeit-Auferstehung, Zur Griechischen und Christlichen Anthropologie und Eschatologie, Freiburg i. Br.,
Freiburger Theologischen Studien 128, 1984.

51. Tomás de Aquino, Summa Theologiae, Turín-Roma, Marietti, 3ํㅡㄹ ed., 1965.

52. Wolff, H. W., Antropología del Antiguo Testamento, traducción de S. Talavero, Salamanca, Sígueme, 1975. 